\title{
تنفيذ تعليم الشخصية \\ دراسة تحليلية في معهد العناية باندونج
}

Mohammad Rindu Fajar Islamy', Udin Supriadi², Rama Wijaya Abdul Rojak ${ }^{3}$, Usup Romli ${ }^{4}$, Saepul Anwar ${ }^{5}$, Muhamad Parhan ${ }^{6}$

1, 2, 3, 4, 5, 6 Universitas Pendidikan Indonesia

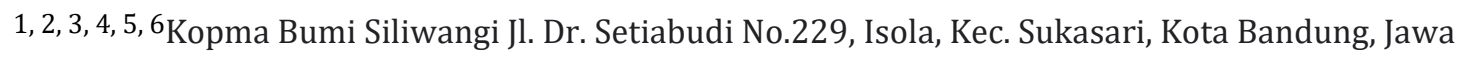
Barat 40154

Email: fajarislam2000@upi.edu¹, udinsupriadi@upi.edu², ramawijaya@upi.edu³ usupromli@upi.edu' ${ }^{4}$,saepulanwar@upi.edu ${ }^{5}$,parhan.muhamad@upi.edu ${ }^{6}$

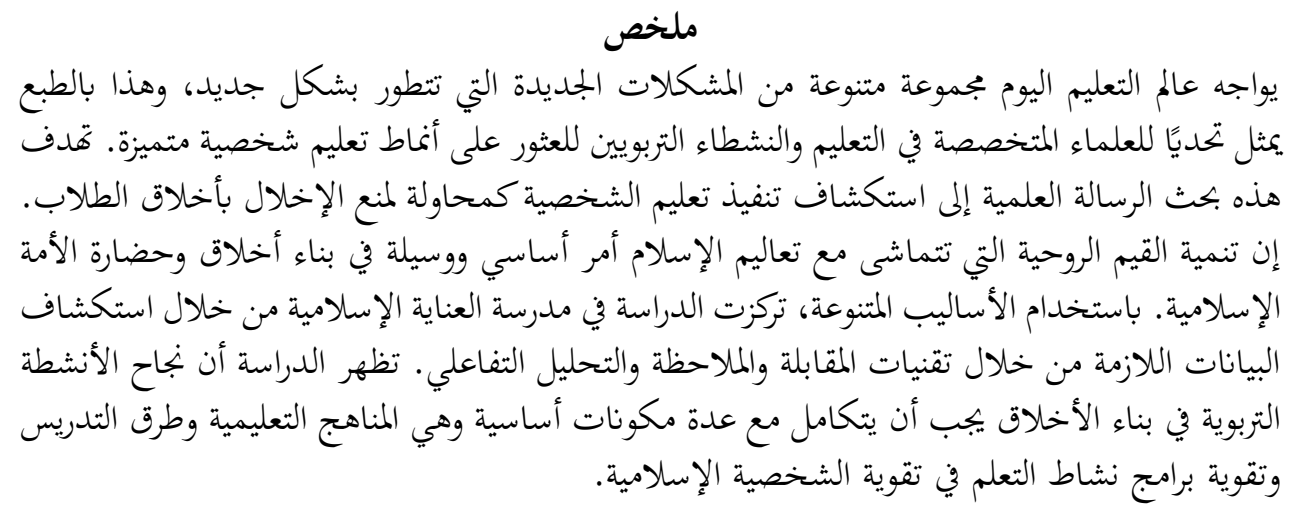

\section{Abstrak}

Dunia pengajaran saat ini menghadapi berbagai problem baru yang terus berkembang. Tentu saja, ini menjadi tantangan bagi para ilmuan dalam pengajaran dan aktivitas pendidikan untuk dapat menemukan tipe pengajaran kepribadian yang baik. Penelitian ini bertujuan mengungkap penerapan pengajaran kepribadian sebagai usaha untuk memerangi kerusakan akhlak pada siswa. Pengembangan nilainilai rohani yang sejalan dengan ajaran Islam adalah hal yang mendasar sebagai instrumen dalam membangun akhlak dan peradaban umat Islam. Dengan berbagai metode, penelitian di Madrasah al-Inayah al-Islamiyah dilakukan dengan menyingkap data-data primer melalui teknik wawancara, observasi, dan analisis interaktif. Penelitian ini menemukan, bahwa keberhasilan aktivitas pendidikan dalam membangun akhlak, harus terintegrasi dengan beberapa komponen pokok, yaitu kurikulum, metode pengajaran, penguatan program kegiatan pembelajaran, demi memperkuat kepribadian Islam siswa.

$$
\begin{aligned}
& \text { الكلمات المفتاحية } \\
& \text { التنفيذ، تعليم الشخصية، المشاكل، مدرسة العناية الإسلامية المعات }
\end{aligned}
$$

How to Cite: Islamy, M. R. F., Supriadi, U., Rojak, R. W. A., Romli, U., Anwar, S. \& Parhan, M. (2020). تنفيذ تعليم الشخصية دراسة تحليلية في معهد العناية باندونج (2) Lentera Pendidikan : Jurnal Ilmu Tarbiyah dan Keguruan, 23(2), 343-356. https://doi.org/10.24252/lp.2020v23n2i13. 
كان للتقدم التكنولوجي الحالي تأثير كبير على تطور عالم التعليم في إندونيسيا. العديد من الجوانب

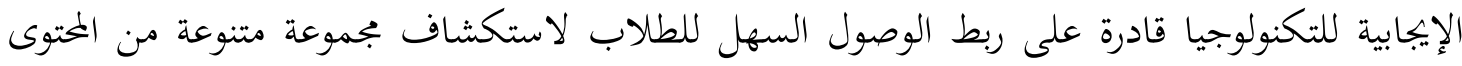

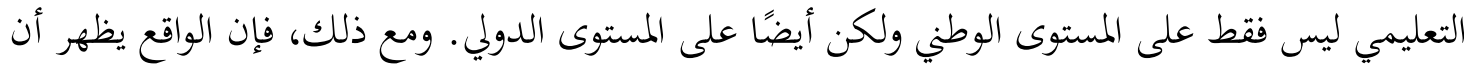

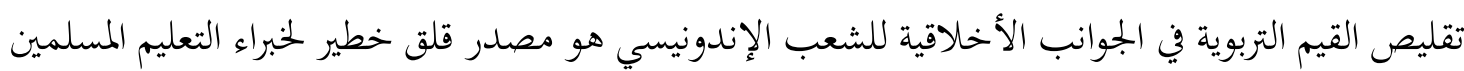

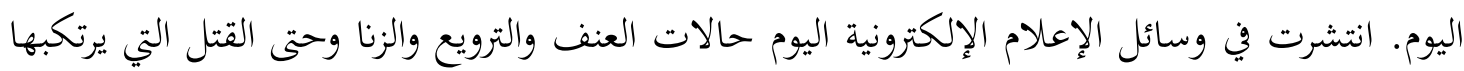

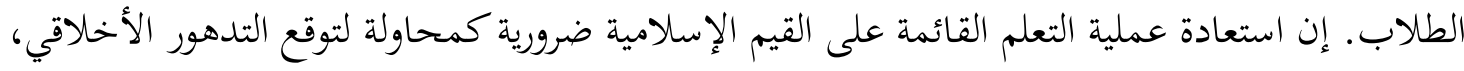

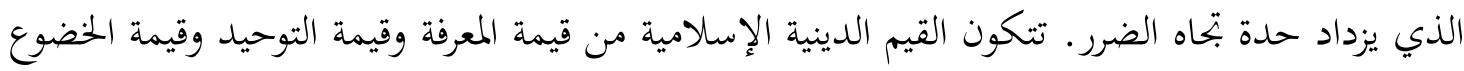

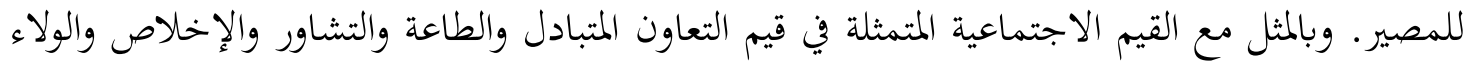

.(Lizawati \& Uli, 2018)

يجب أن يبدأ التعليم الجيد من العوامل الفلسفية التربوية كأساس متين للإِيمان في غرس القيم الأولية للإخلاص في الطلاب (Mansor et al. 2019). يجب دمج قيم الشخصية الإسلامية في مؤسسات التربية

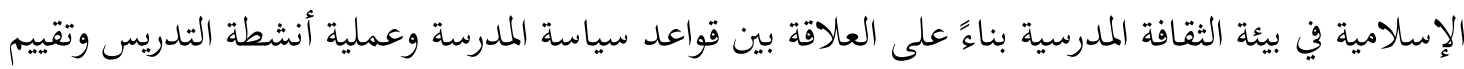

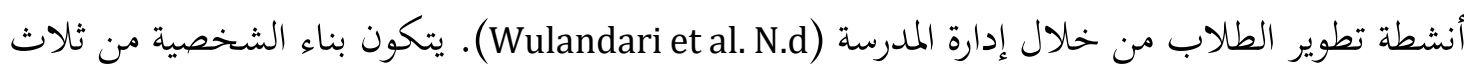

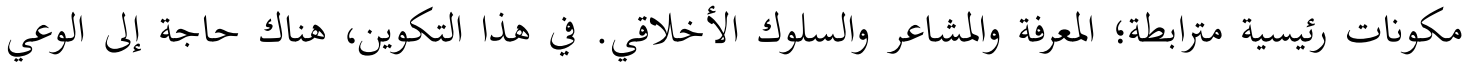

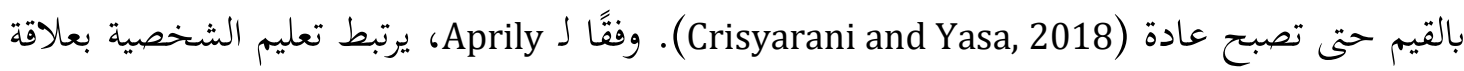

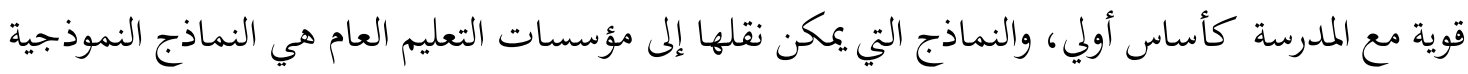

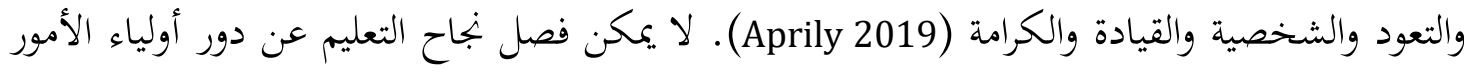
والمعلمين في تنمية الشخصية الطلابية (Ramdan and Fauziah, 2019). يتطلب الأمر تآزرًا من الآباء

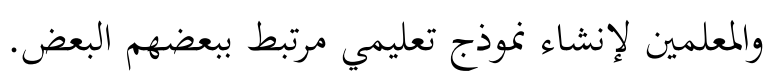

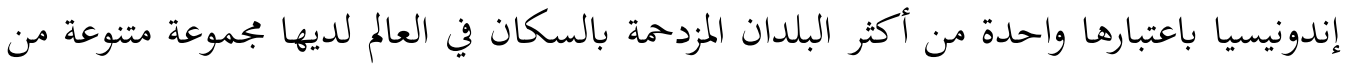

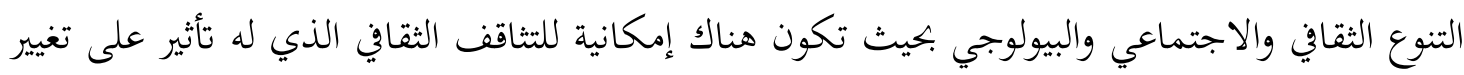

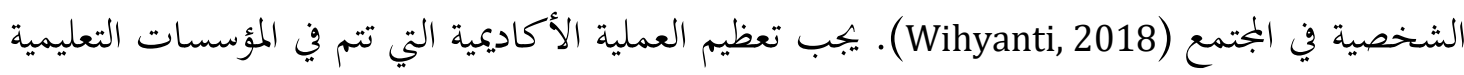

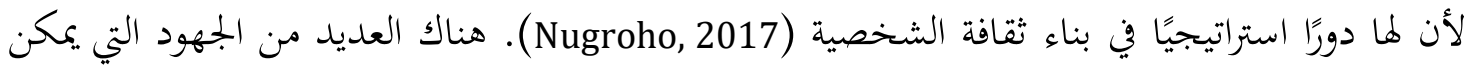

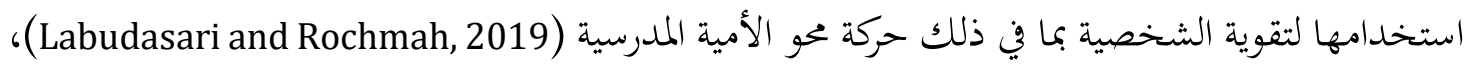

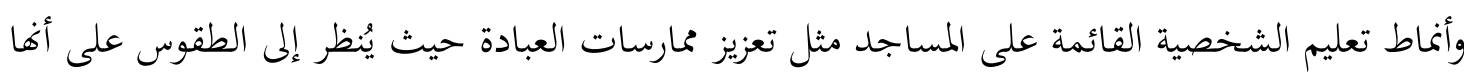
قادرة على تطوير شخصية الطاعة والمسؤولية والانضباط والجدارة بالثقة والرعاية و الشجاعة ( Badrudin 
من الشرح السابق ترتبط المشكلات في عالم التعليم ارتباطًا وثيقًا بنجاح أو فشل كيفية بتحسيد

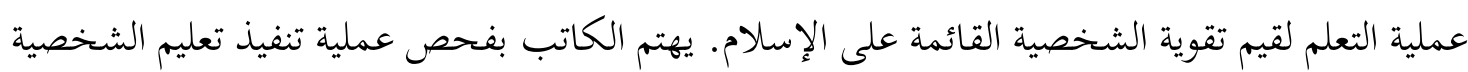

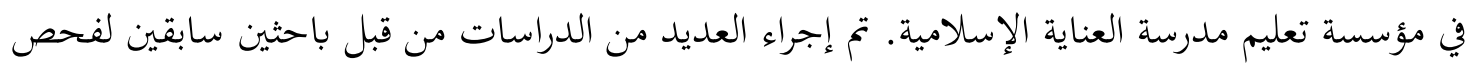

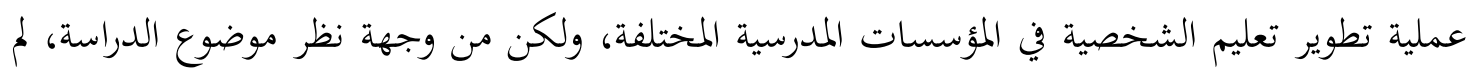

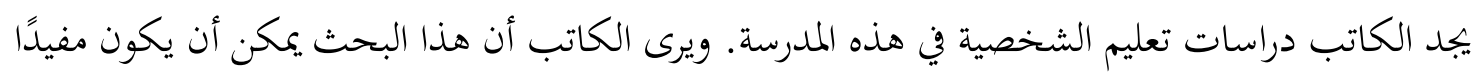
للكنوز العلمية، خاصة في مجال التعليم.

البحث السابق

تعتبر تربية الشخصية نقطة جذب للمفكرين المسلمين في بجال التربية للابتكار دائمًا للبحث عن

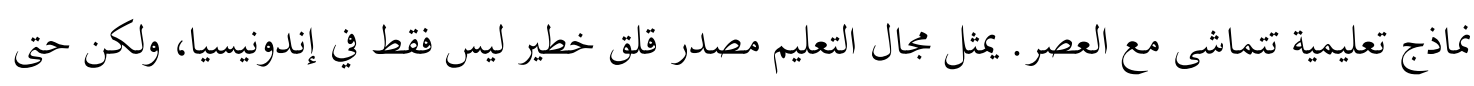

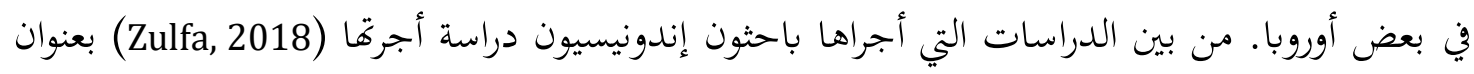
Model of Islamic Religion Education 435 Based On Islam Nusantara On College الدراسة حلاً بديلاً لنموذج التعليم الديني الإسلامي القائم على الحضارة الإندونيسيا في التعليم العالي، ووفقًا له فإن هذا النموذج له مساهمة كبيرة في تعزيز الشخصية.

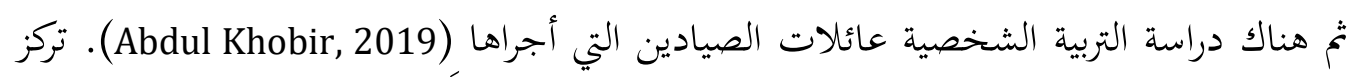

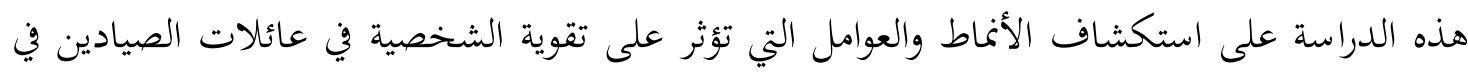

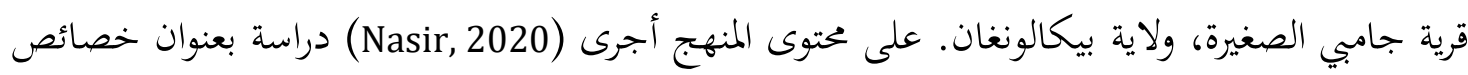

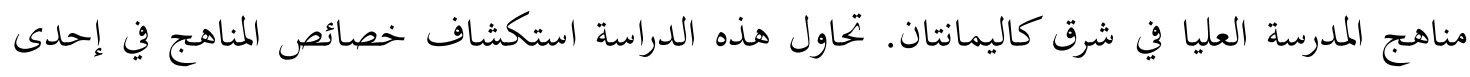

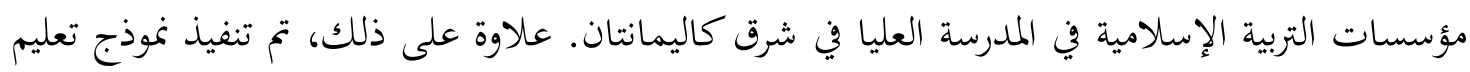

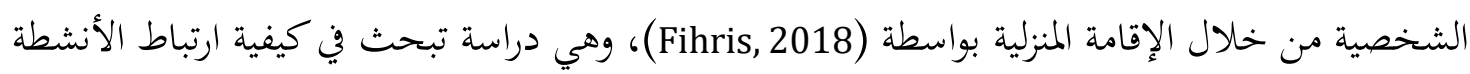

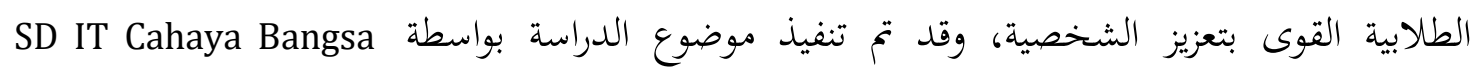

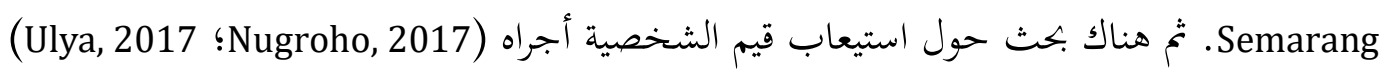

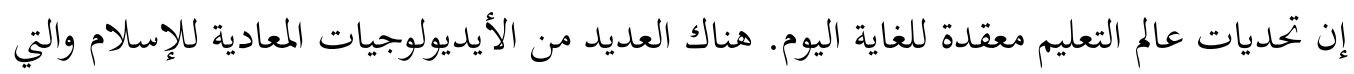

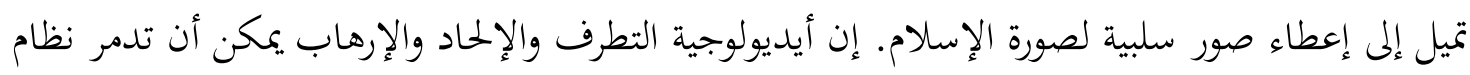

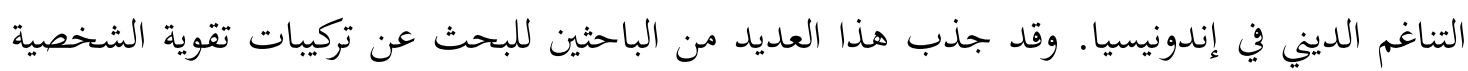

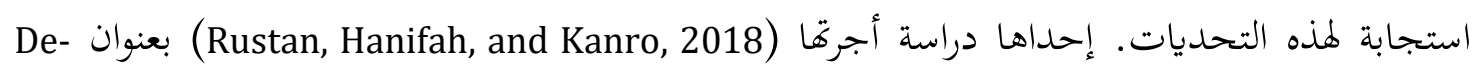
radicalization in the Implementation of Islamic Education Curriculum in SMA Masamba South Sulawesi

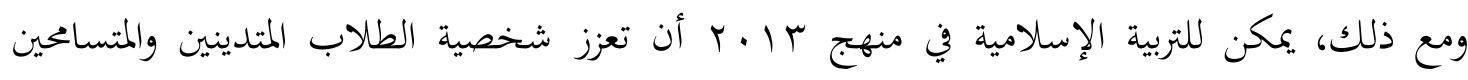




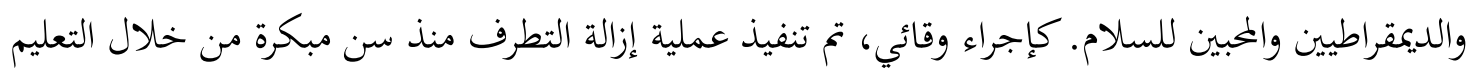

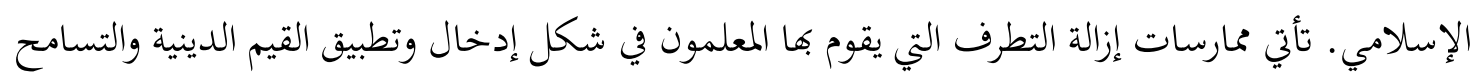

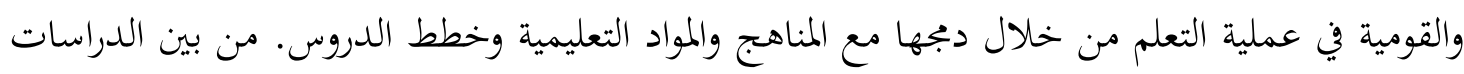

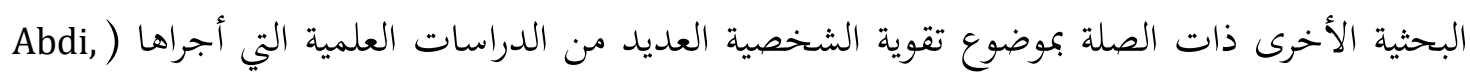

(.S. A. P ؟Nurdin, 2015 ؟Fery n.d ؛Arifin, 1970 2018

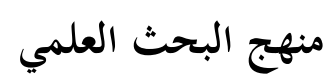

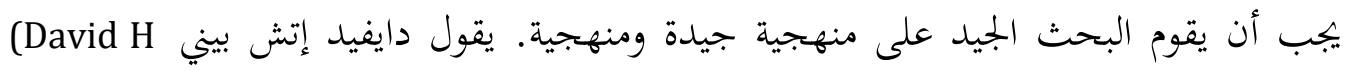

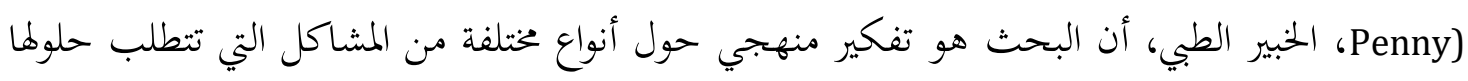

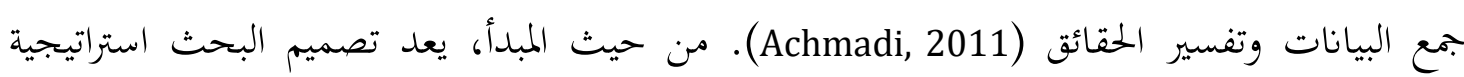

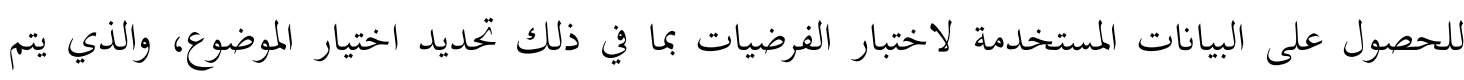

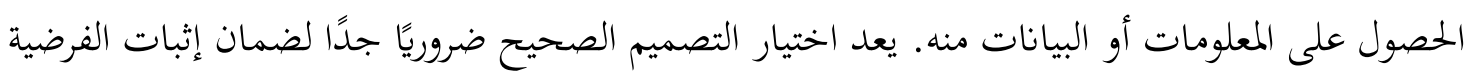

التي تم بناؤها (Dharminto, 2007).

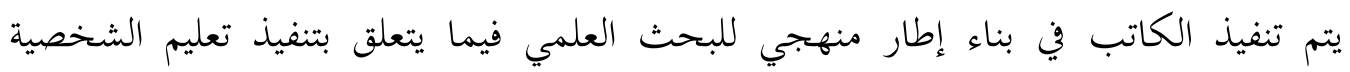

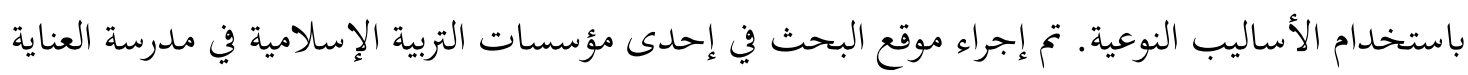

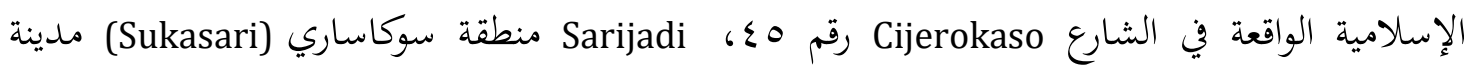

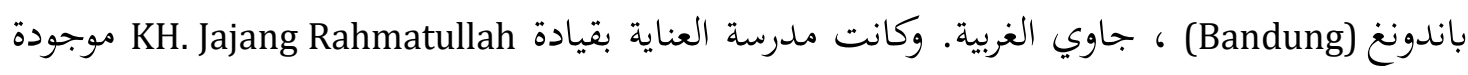

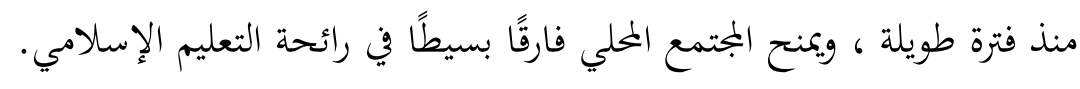

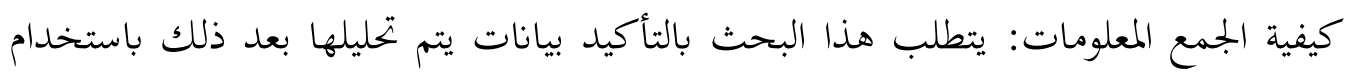

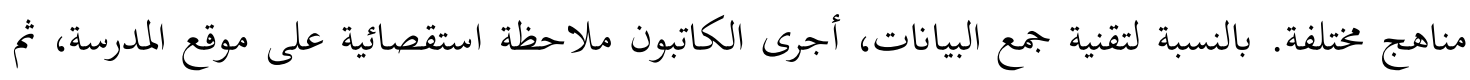

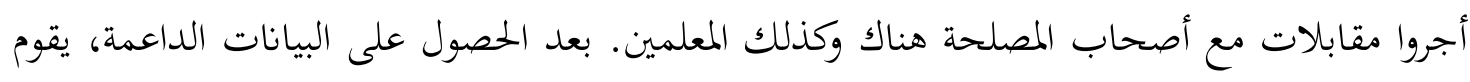
الكاتب بعد ذلك بتحليل البيانات بشكل تفاعلي، بحيث يتم تكوين الفرضية الأولية.

\section{مفهوم التربية في الإسلام}

القيم الإسلامية هي جانب أساسي من جوانب حياة الإنسان (Al-Hazimi, 2000). هذه القيم

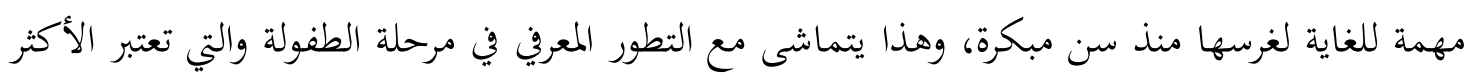

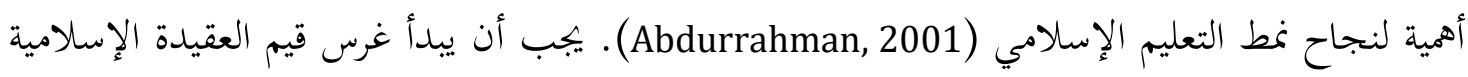

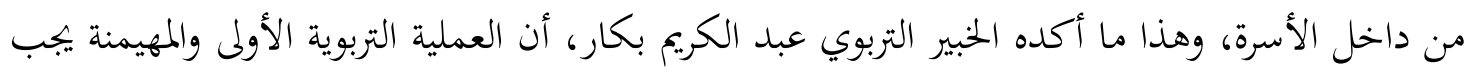

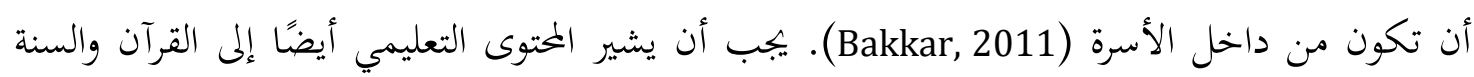

.(Ali, 2002) 
يقول الله سبحانه وتعالى:

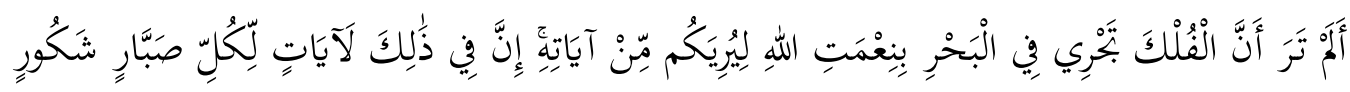

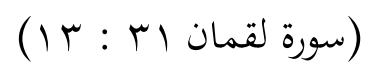

من الآية السابقة، يصف الله سبحانه وتعالى كيف أن العملية الناجحة للتربية الأسرية التي يقوم بها لقمان تبدأ بتحقيق قيم الإيمان في ولده، أي الإيمان بالله وعدم إدانته. يجب ألهان أن تشير مبادئ العقيدة إلى لى الوحي، أي القرآن (As-Syarif, 2001)، لأن الشخص الوحيد الذي حصل فيد على الشرعية من الله سبحانه وتعالى لن يكون فيه تحريف للمعنى والتعاليم (Ali . . . ب). النبي محمد عليه الصلاة والسلام هو المثال الرئيسي المتعلق بكيفية بدء عملية تعليم الشخصية من تنمية الأسرة. الأب يرعى الأم والأطفال ليكونوا أقرب إلى الله سبحانه وتعالى.

التربية الإسلامية هي المفهوم التربوي الوحيد الذي يجعل معنى وهدف التعليم أعلى بكيث يوجه الإنسان إلى رؤية مثالية ويمنع الناس من الانزلاق والانحراف. بسبب الإسلام، فإِان للتعليم مهمة كخادم للإنسانية في تحقيق سعادة الفرد والمجتمع. وهذا يعني أن الإسلام سينجح في تحقيق أهداف التعليم التي كانت هاجسة قادة التعليم الغربي (Rusmin B., 2017). يجب أن يقوم مصدر التربية الإسلامية على القرآن والسنة والاجتهاد الذي يقوم به العلماء. من خلال إعادة جزء التعليم إلى إطار يقوم على أهداف دينية، إنها لن تخطئ البشرية أبدًا، لأن الوحي سيوجه حدود العقل البشري. يتطلب تطوير عالم التعليم نحو الحداثة موازنة منهجية حتى لا ينحرف ابتحاه التعليم عن القيم الروحية.

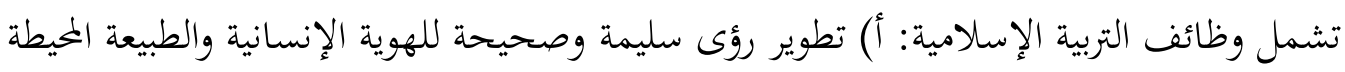
والعظمة الإلهية، ب) تحرير الإنسان من جميع العناصر التي يمكن أن تحط من كرامة الإنسان، ج) تطوير

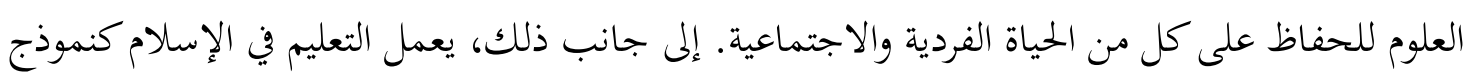

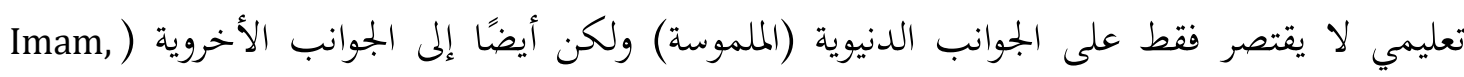

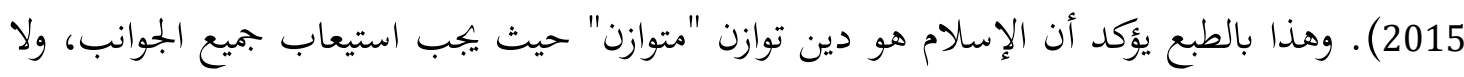
ينبغي بتحاهل بعضها البعض. من ناحية أخرى، يجب أن بحسد التربية الإسلامية المبادئ الأساسية في عملية

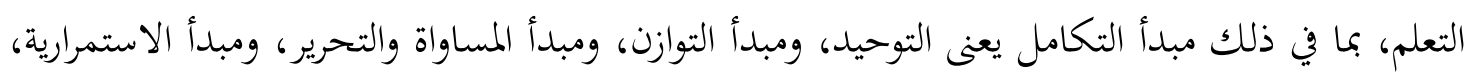
ومبدأ المنفعة.

\section{مراحل التعليم الشخصية في المنزل أو البيت}

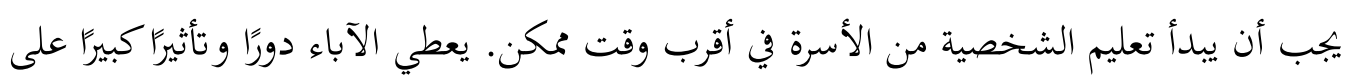
تنمية شخصية الطفل. تعليم الشخصية في الأسرة في أقرب وقت ممكن ببطء، حيث اعتاد الأطفال أولاً على العيش في بيئة إيجابية. يجب على الآباء والأشخاص حول المنزل بحسيد الشخصيات الإيجابية والإيمان 
مثل أداء الصلاة والمشاركة والتحدث بأدب وصدق. ثم يجب على الأبناء تنفيذ هذه الشخصية في الحياة

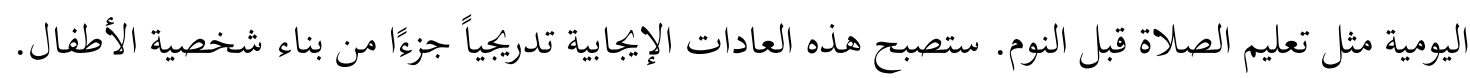

\section{مراحل التعليم الشخصيات في الممدرسة}

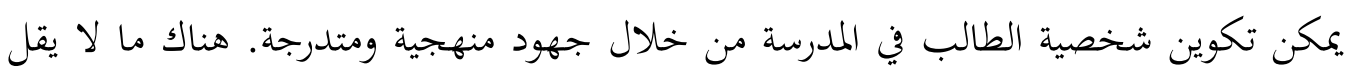

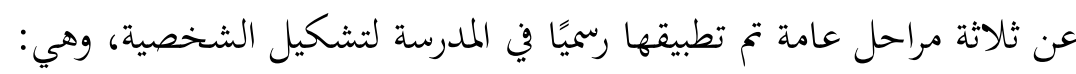
أ) مرحلة المعرفية (Knowledge)

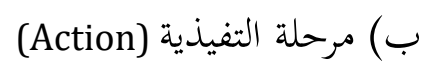
ج) مرحلة العادة (ب) مرحلة الثفيلة (Habits)

يمكن استخدام كل نشاط للطلاب في المدرسة كوسيلة لغرس الشخصية وتطوير السلوك وتسهيل

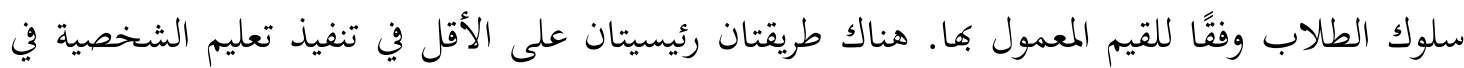

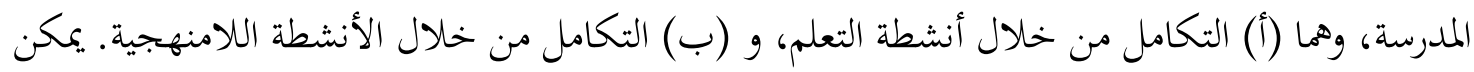

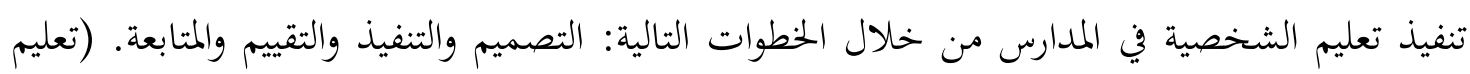
الشخصية في المدرسة)

\section{مراحل التعليم الشخصيات في الججتمع}

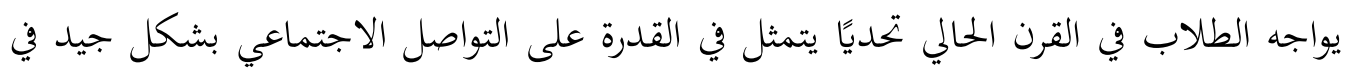

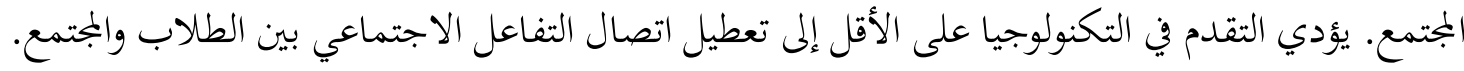

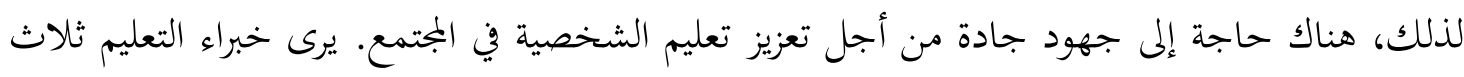

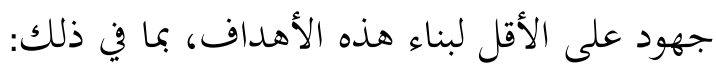

$$
\begin{aligned}
& \text { أ) مرحلة التقديم } \\
& \text { ب) مرحلة استيعاب القيمة }
\end{aligned}
$$

ج) المرحلة الفردية من الوجود (Suyanta, 2013)

\section{عناصر المسمى مختلف من تعليم الإسلام}

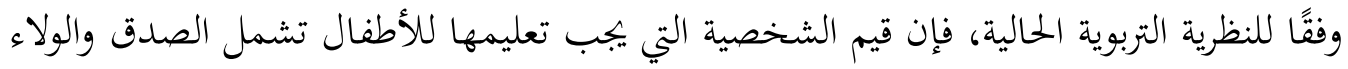

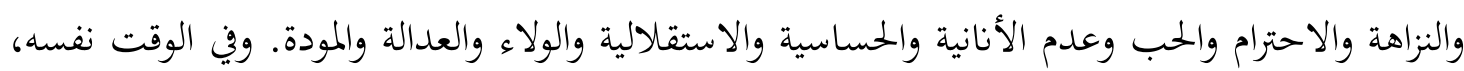

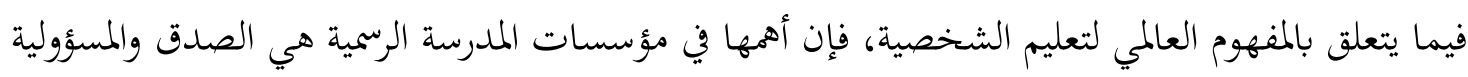
والذكية والصحية والنظيفة والرعاية والإبداع والتعاون المتبادل. 


\section{منهج المفهوم والتعليم في مدرسة العناية الإسلامية}

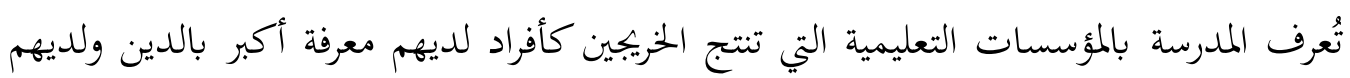

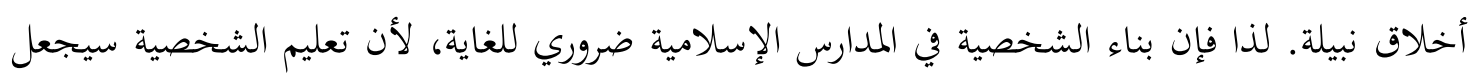

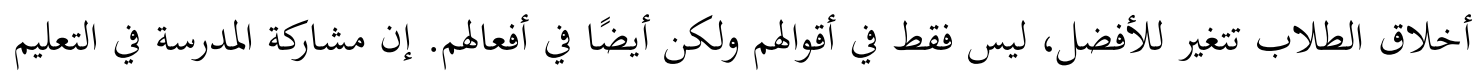

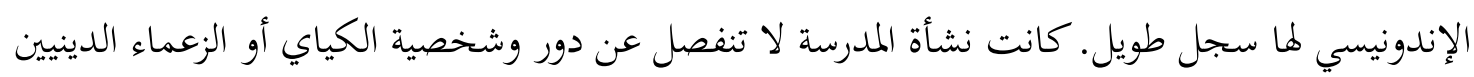

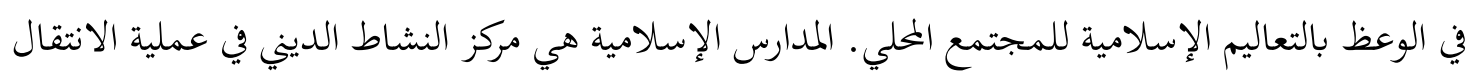

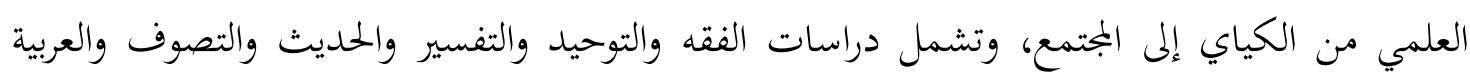
وكذلك الدراسات العلمية الإسلامية.

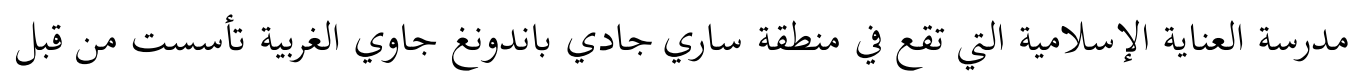

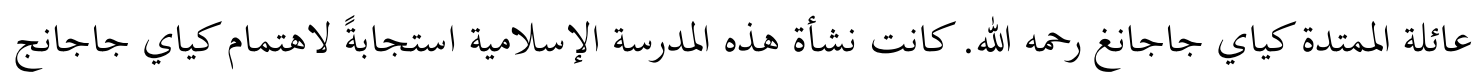

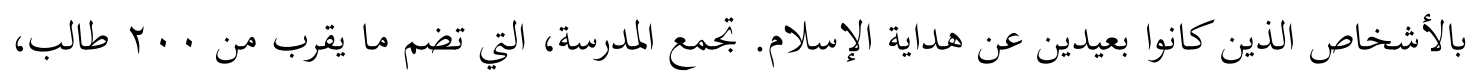

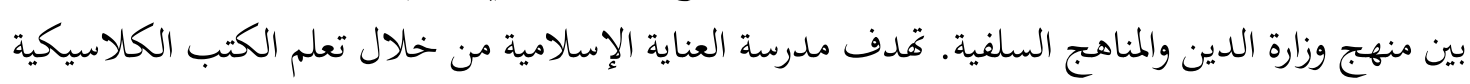

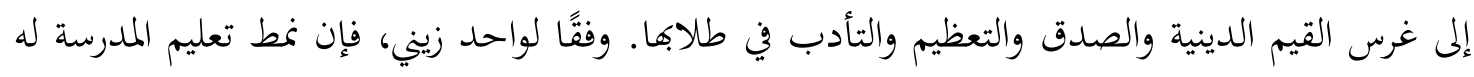

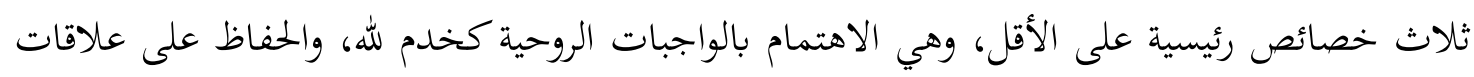

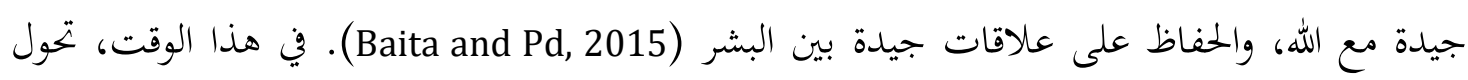

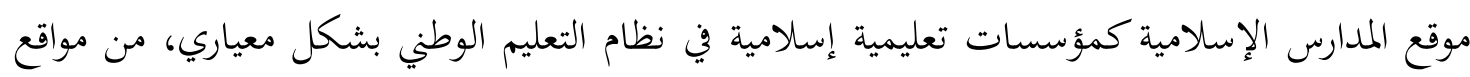

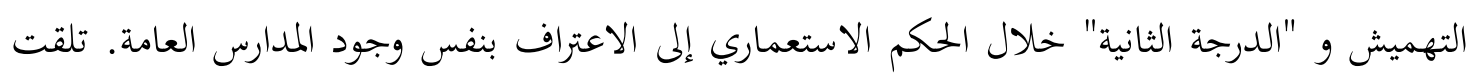

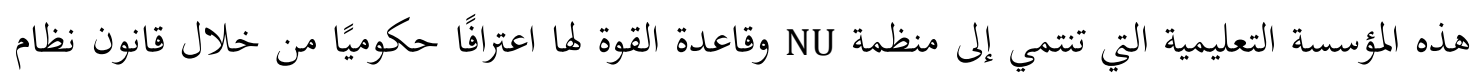

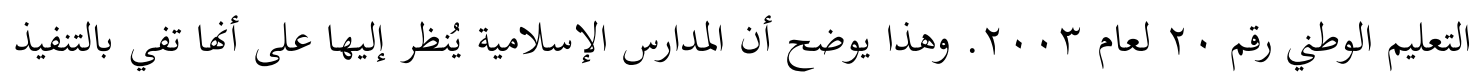
الإلزامي للتعليم الإلزامي الذي أعلنته الحكومة (بام (Hasibuan 2013).

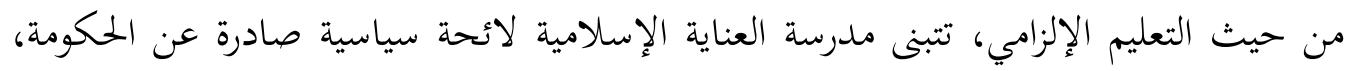

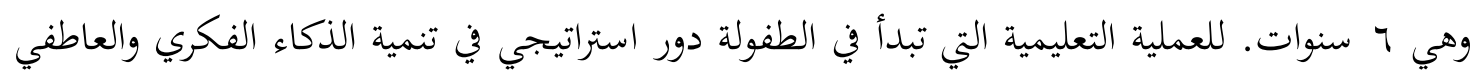

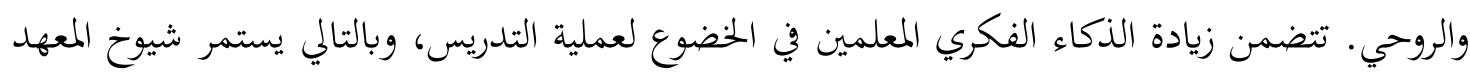

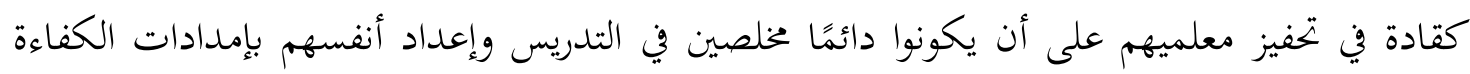

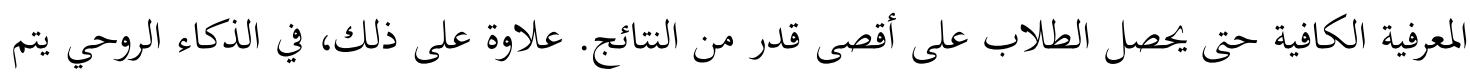

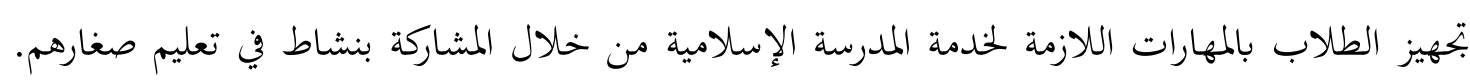

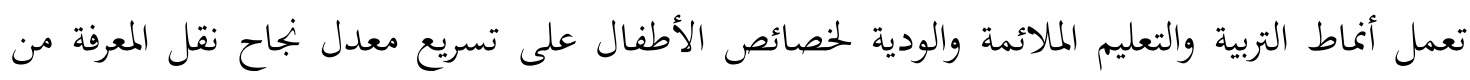

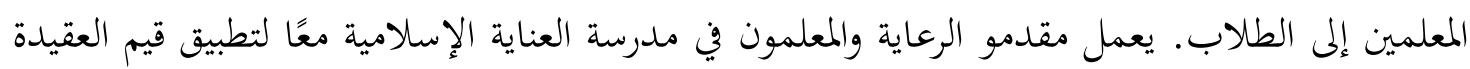
الإسلامية ومراقبة مسار عملية التعلم. 


\section{منهج التعليم في مدرسة العناية الإسلامية}

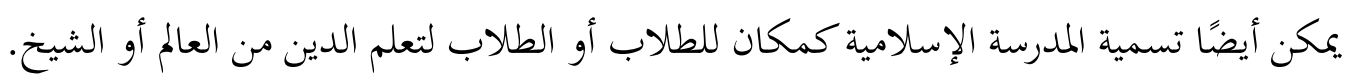

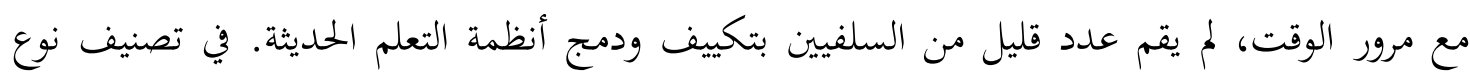

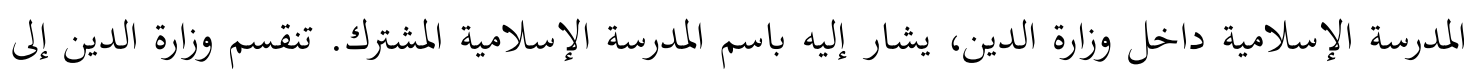
ثلاثة أنواع من المدرسة الإسلامية، وهي مدرسة السلفية الإسلامية، والمدارس الخلفية الإسلامية المارية (Ashriyah)

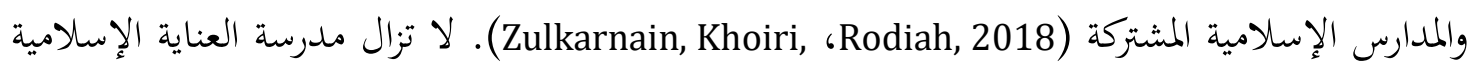

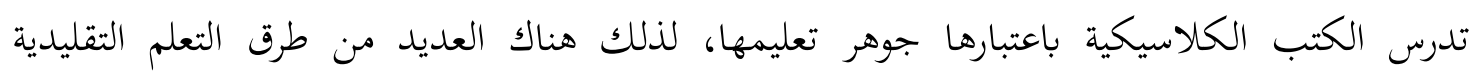

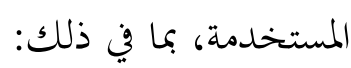

\section{طريقة سوروجان (Sorogan)}

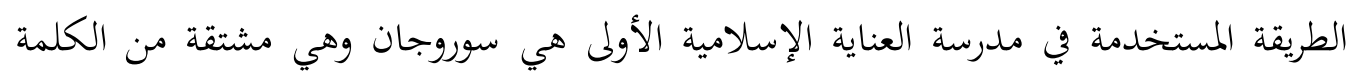

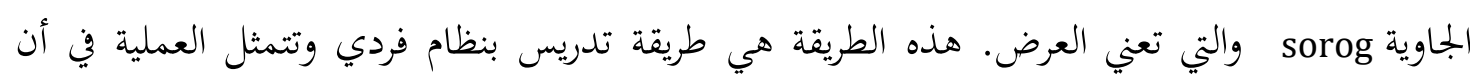

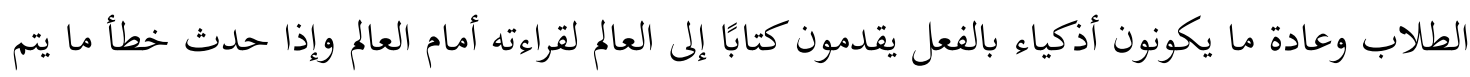

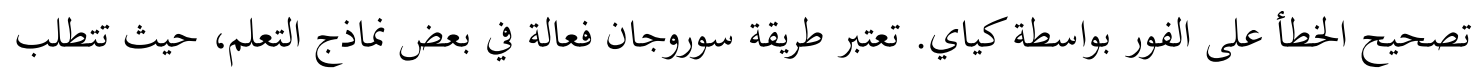

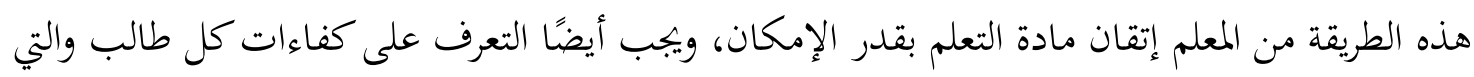

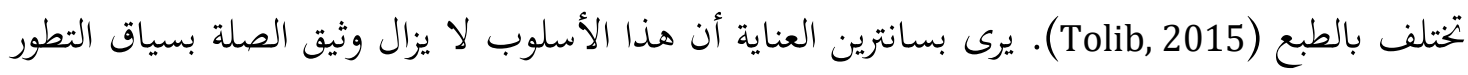

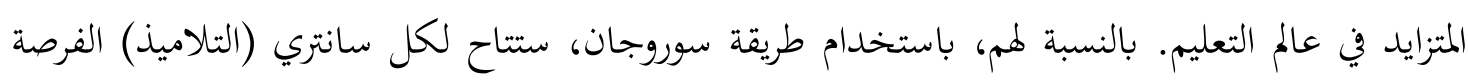

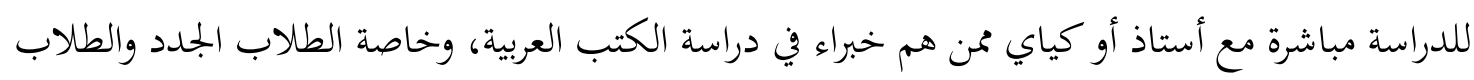

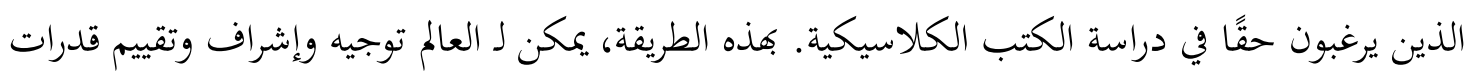

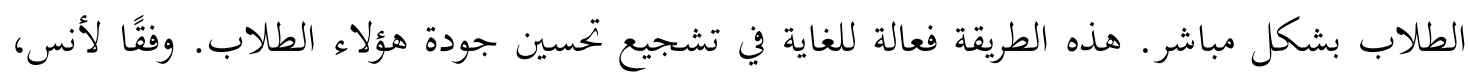

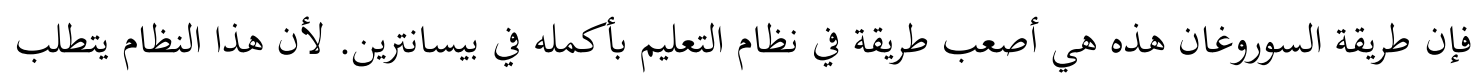

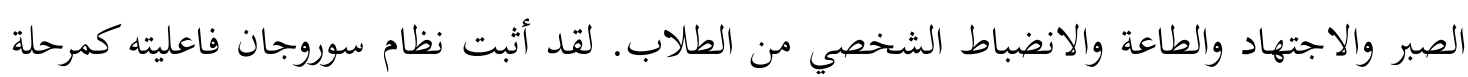

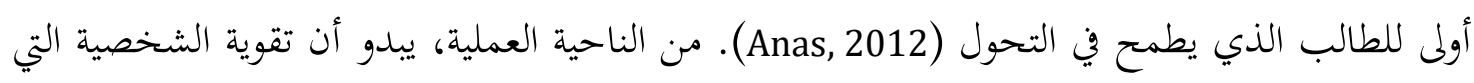

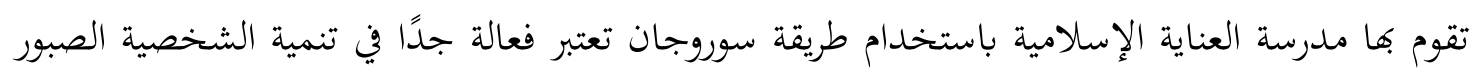
والمثابرة والمطيعة والمنضبطة.

\section{طريقة باندونغان (Bandungan)}

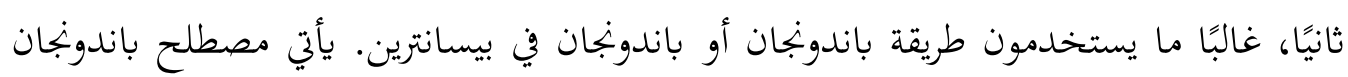

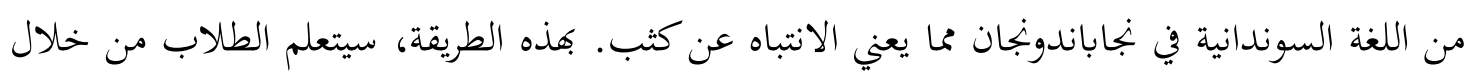

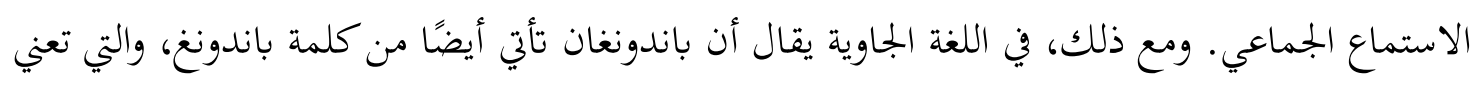

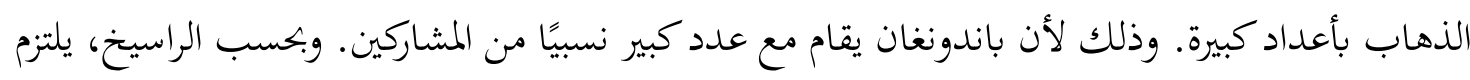




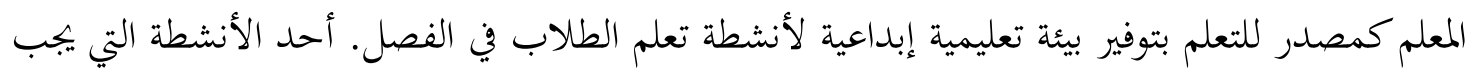

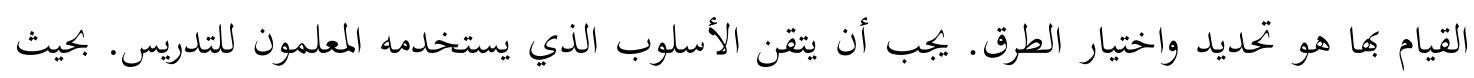
يككن عند استخدامه تكوين جو من التفاعل التربوي (Rasikh, 2018).

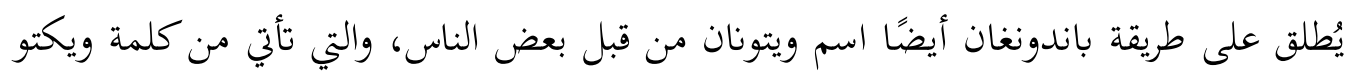

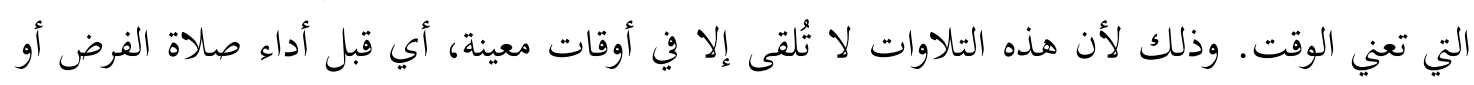

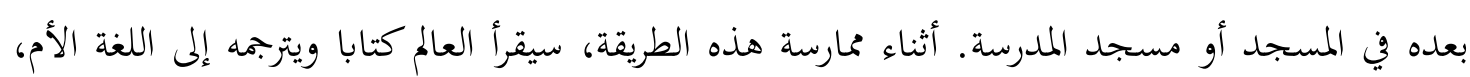

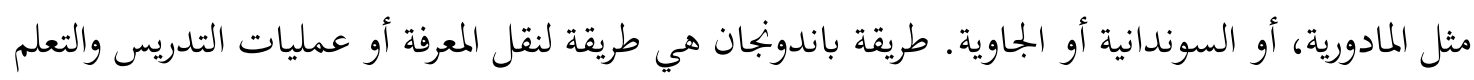

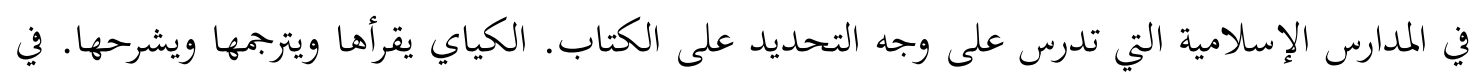

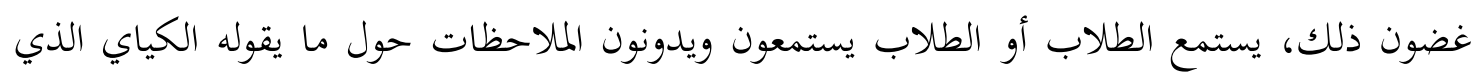

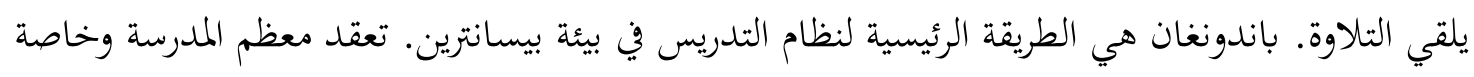

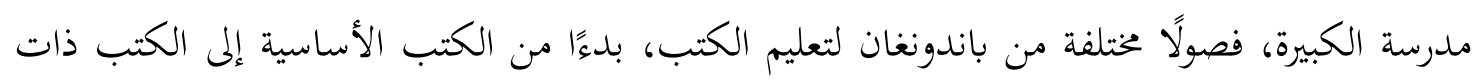

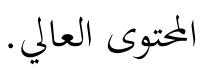

\section{طريقة لالاران (Lalaran)}

ثالثًا، طريقة لالاران هي طريقة تعلم يتم فيها تأدية الدرس بأغاني معينة، وهذه الطريقة لا تنطبق

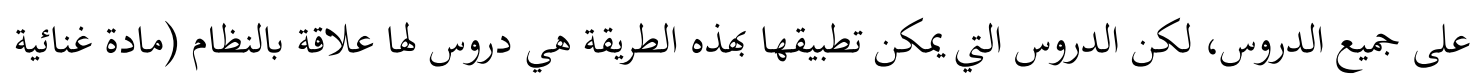

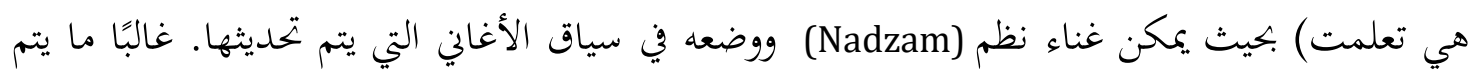
استخدام طريقة اللالاران هذه في الدروس التي تحتوي على نظم مثل: العمريطى، ألفية ابن مالك، إلخا.

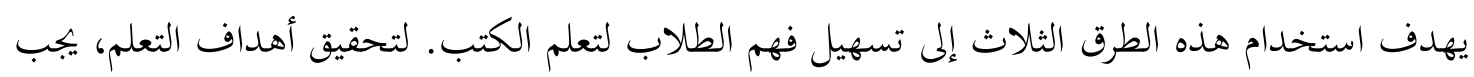

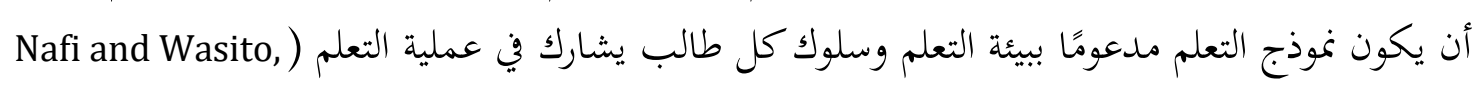

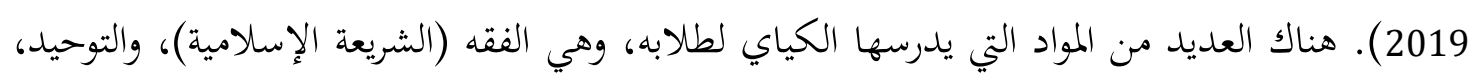

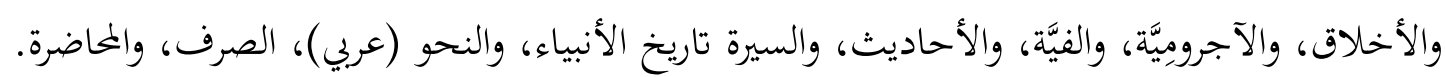

تنفيذ بناء الشخصية

في مدرسة العناية الإسلامية، يُطلب من الطلاب المشاركة في الأنشطة الروتينية للمدرسة الداخلية.

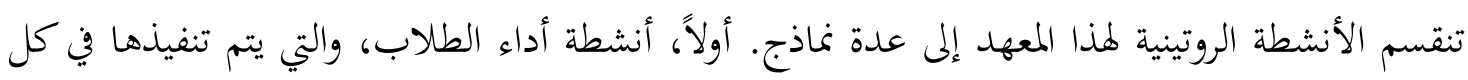

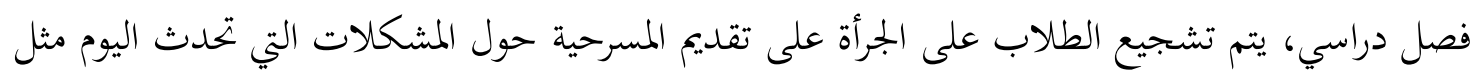

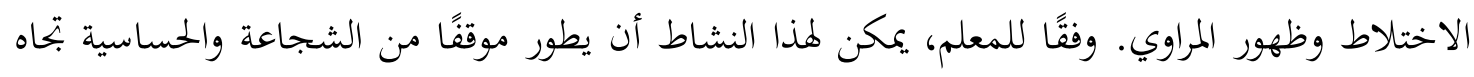

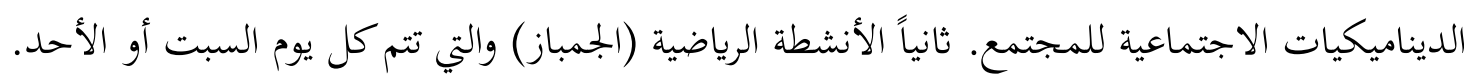

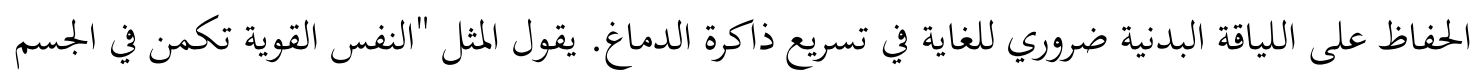




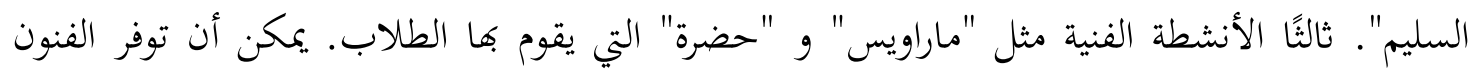

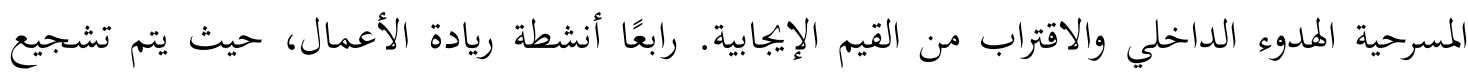

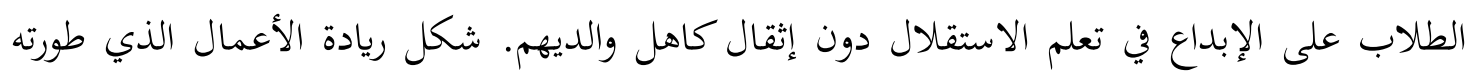

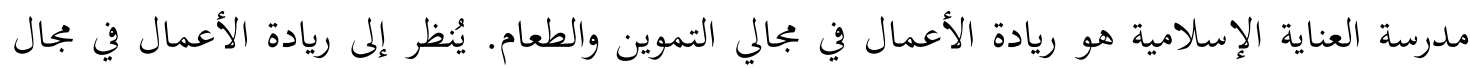

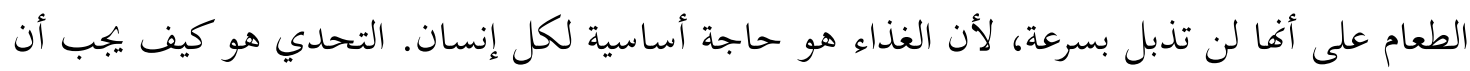

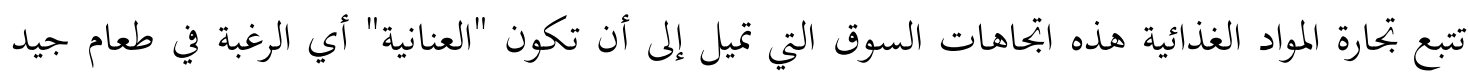

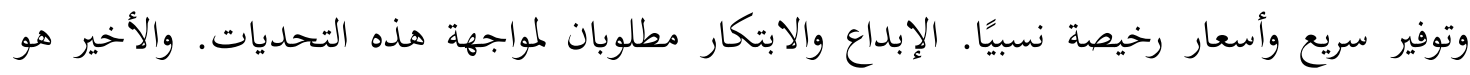

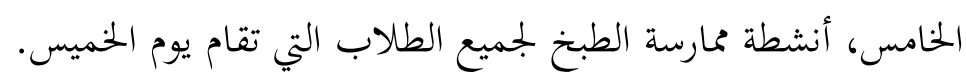

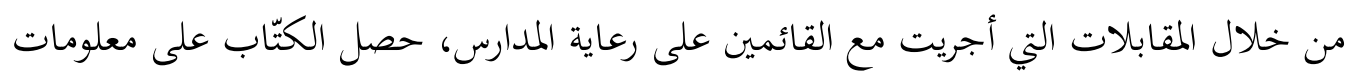

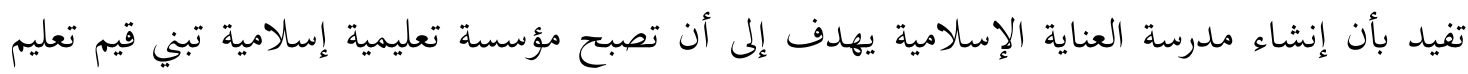

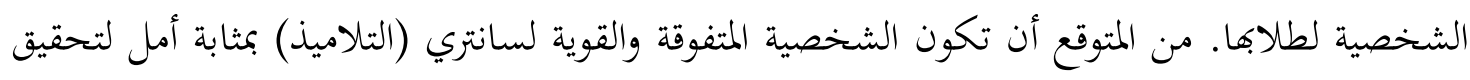

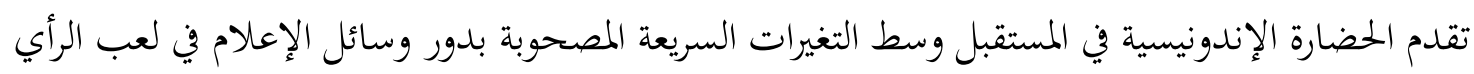

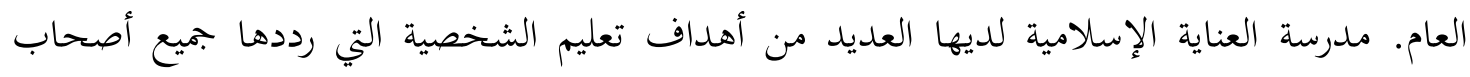
المصلحة، بما في ذلك:

1) غرس الإخلاص لدى الطلاب في القيام بأي نشاط دون إكراه. r r التعود على الحياة البسيطة، وبتحنب الإسراف والحياة الفاخرة.

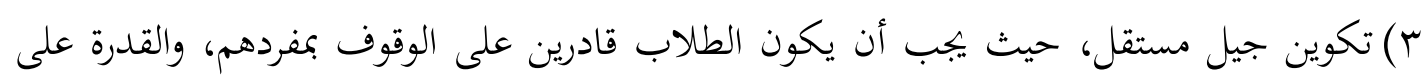
كسب أموالهم الخاصة، وعدم سؤال والديهم دائمًا. ع) متطلبات الانضباط في مختلف المجلات. ه) المحافظة على روح الأخوة والوحدة والأخوة الإسلامية بين المسلمين. (أهم الملامح الشخصية الظاهرة من التنفيذ المتعلم)

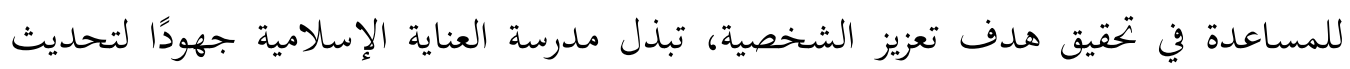

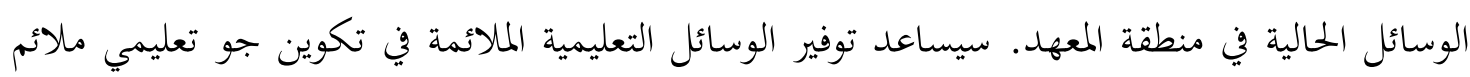

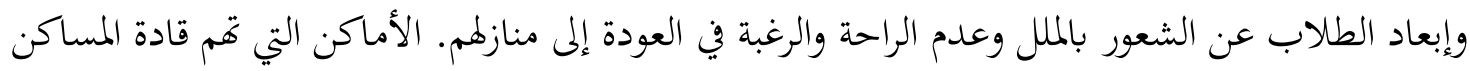

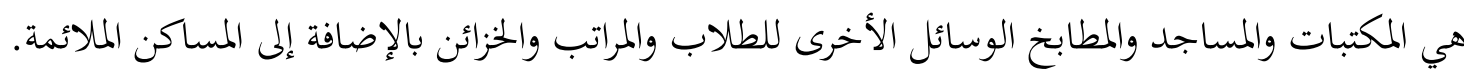
عادة ، يتم ملء غرفة نوم واحدة بحوالي عشرين طالبًا.

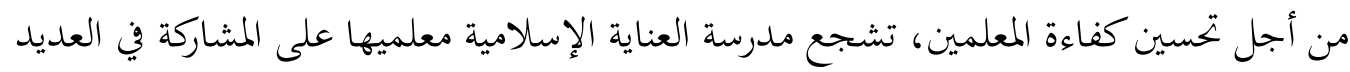

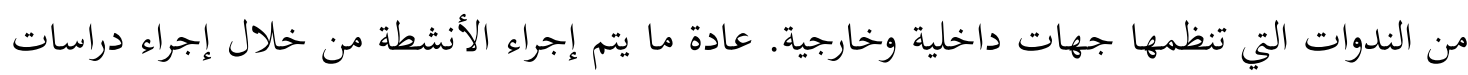

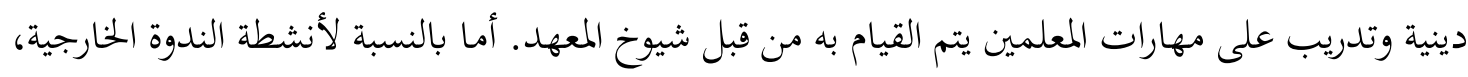


فعادة ما يشارك المعلمون في برنامج تحسين كفاءة المعلمين من قبل وزارة الدين. لا يقوم بعض المدرسين

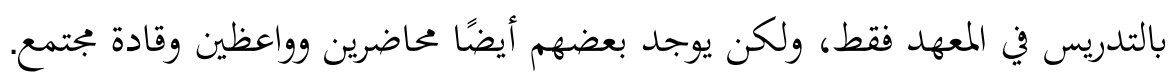

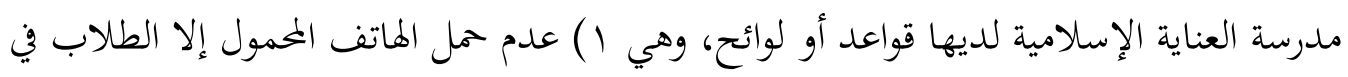

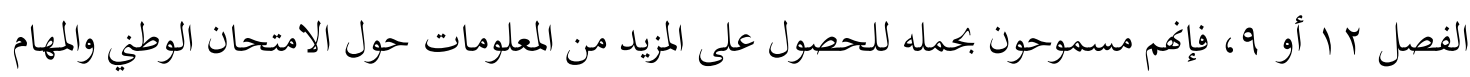

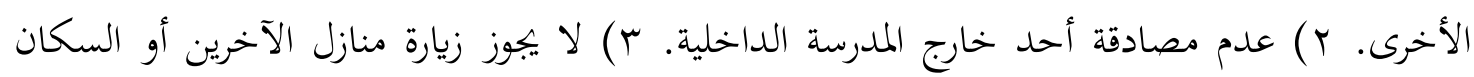

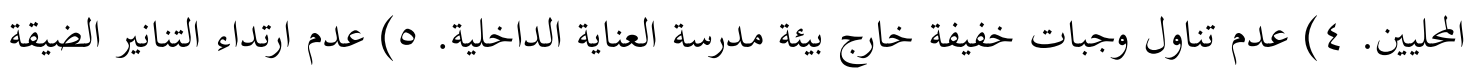

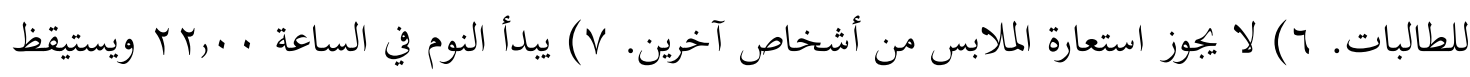

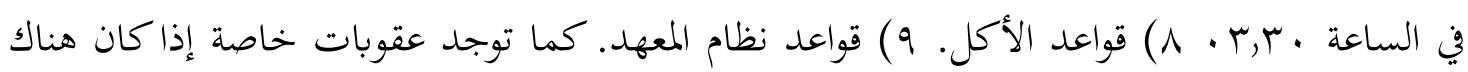

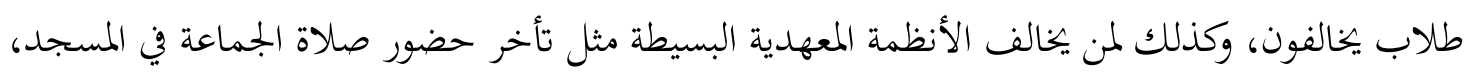

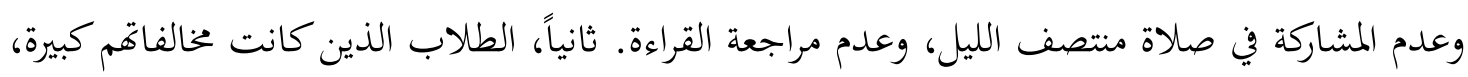

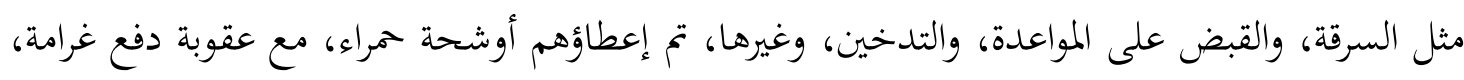

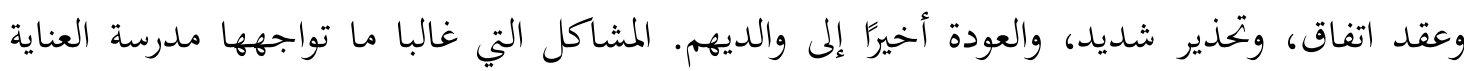

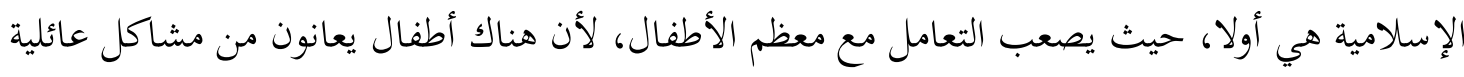

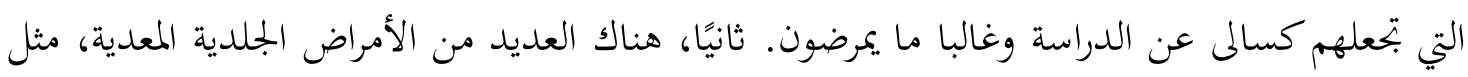

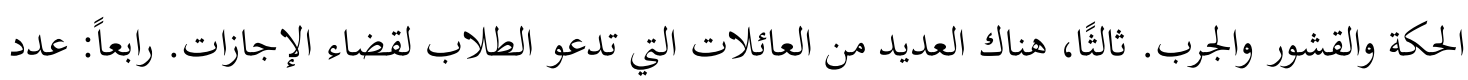
الطلاب الذين فرّوا من المعهد وخاصة الذكور منهم.

الحلاصة

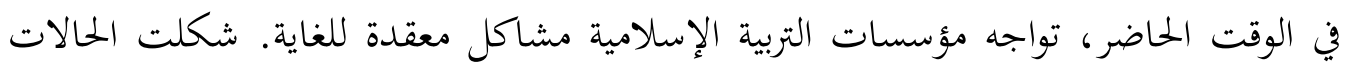

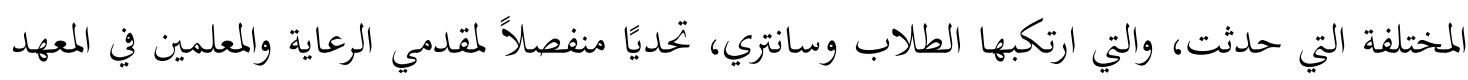

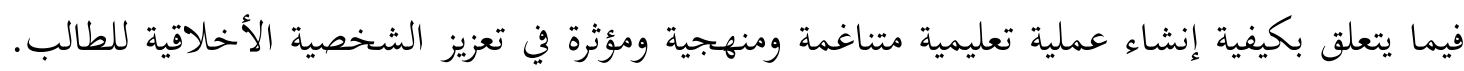

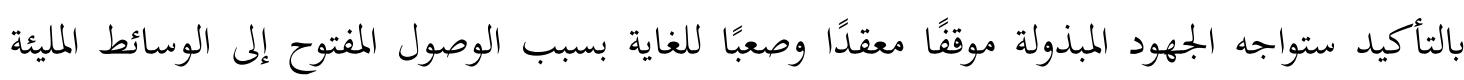
بالمتوى السلبي الذي يمكن أن يضر بأخلاق الطلاب.

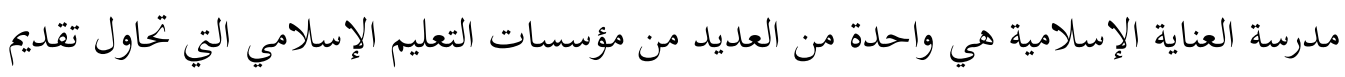

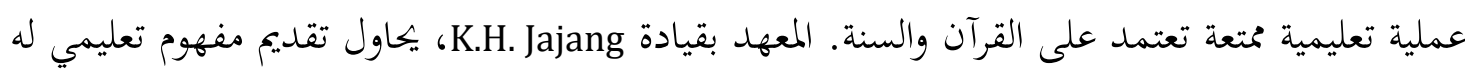

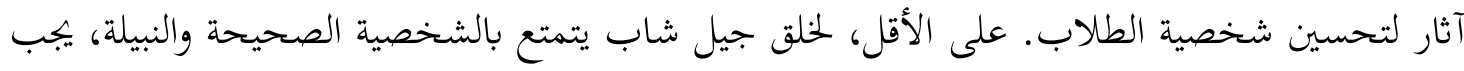

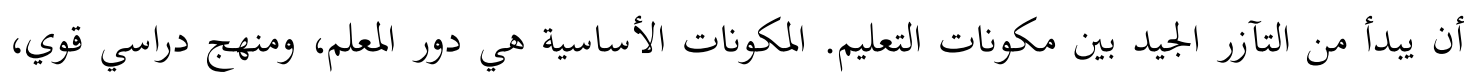

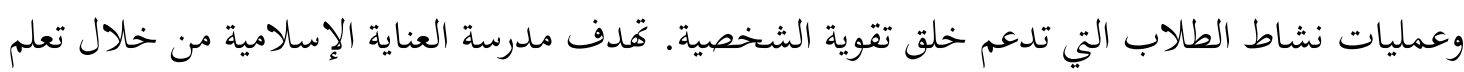

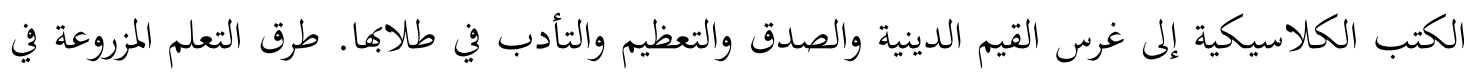



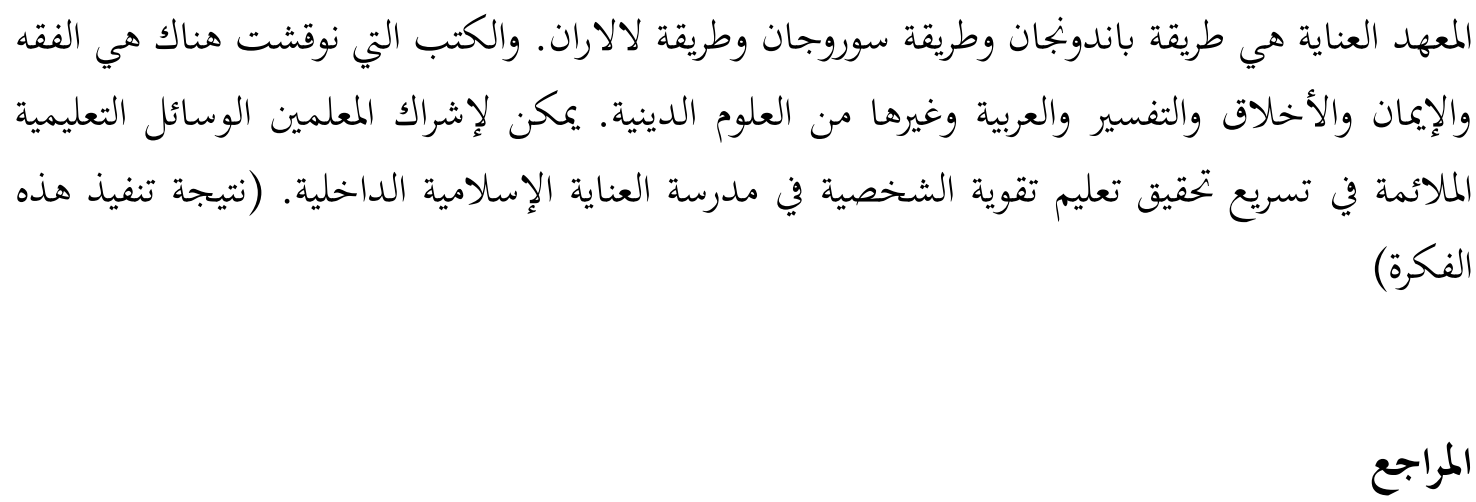

Abdi, Muhammad Iwan. 2018. "The Implementation of Character Education in Kalimantan, Indonesia: Multi Site Studies." Dinamika Ilmu 18(2):305-21. doi: 10.21093/di.v18i2.1289.

Abdul Khobir. 2019. "Potret Pendidikan Karakter Di Kalangan Keluarga Nelayan.” Edukasia Islamika 4(4):42-61. doi: 10.28918/jei.v4i1.2254.

Abdul Karīm Bakkār. 2011. At-Tawāshul al-Usrā kaifa Nuhmī usranā min at-tafakkuk. Riyadh: Dar al-Wujuh.

Abdul Karīm Bakkār. 1430 H. Masaru al-Usrah Mabadi Li Taujih al-Usrah. Riyadh: Muassasah Al-Islam al-Yaum.

Achmadi, Abu \&. Narbuko. 2011. "Teori Metodologi Penelitian.” Teori Metodologi Penelitian $1-21$.

Anas, A. Idhoh. 2012. "Kurikulum Dan Metodologi Pembelajaran Pesantren." Cendekia: Jurnal Kependidikan Dan Kemasyarakatan 10(1):29-44. doi: 10.21154/cendekia.v10i1.400.

Aprily, Nuraly Masum. 2019. “Nidzomul Ma'had Dalam Pendidikan Akhlak Di Pesantren Cipari Kabupaten Garut." Premiere Educandum: Jurnal Pendidikan Dasar Dan Pembelajaran 9(2):141. doi: 10.25273/pe.v9i2.4987.

Arifin, Zainal. 1970. "Pendidikan Multikultural-Religius Untuk Mewujudkan Karakter Peserta Didik Yang Humanis-Religius." Jurnal Pendidikan Islam 1(1):89. doi: 10.14421/jpi.2011.11.89-103.

Badrudin, Badrudin. 2020. "The Management of Strengthening the Mosque-Based Religious Character Education." Nadwa 13(2):179. doi: 10.21580/nw.2019.13.2.4106.

Baita, M. Holil, and Putra M. Pd. 2015. "Salafiyah Dalam Menghadapi Era Modern." Al Insyiroh: Jurnal Studi Keislaman 100-117.

Chrisyarani, Denna Delawanti, and Arnelia Dwi Yasa. 2018. "Validasi Modul Pembelajaran: Materi Dan Desain Tematik Berbasis PPK." Premiere Educandum: Jurnal Pendidikan Dasar Dan Pembelajaran 8(2):206. doi: 10.25273/pe.v8i2.3207.

Dharminto. 2007. "Metode Penelitian Dan Penelitian Sampel." British Journal of Educational Studies 55(4):468-69.

Fery, Eka. n.d. “Observasi Sistematik Pada Pembelajaran Aqidah Akhlaq A . Pendahuluan Penilaian Non-Test Merupakan Penilaian Yang Di Gunakan Untuk Mengukur 
Keberhasilan Peserta Didik Dalam Menyerap Pelajaran Dengan Menggunakan Alat Penilaian Nontes Ini Yakni Berupa Observ." 10(2):391-412.

Fihris, Fihris. 2018. "Model Pendidikan Karakter Melalui Homestay Di SDIT Cahaya Bangsa Semarang." Edukasia Islamika 3(2):131. doi: 10.28918/jei.v3i2.1684.

Hasibuan, Riadul Muslim. 2013. "SISTEM PENDIDIKAN PONDOK PESANTREN SALAFIYAH DI ERA MODERN.” Universitas Islam Negeri Sultan Syarif Kasim Riau.

Imam, Syafe'i. 2015. "TUJUAN PENDIDIKAN ISLAM.” Al-Tadzkiyyah: Jurnal Pendidikan Islam, Volume 6, November 2015 6(November):1-16.

Jamāl Abdurrahmān. Athfāl al-Muslimīn Kaifa Rabbāhum an-Nabī al-Amīn. Mekkah: Dār Thayyibah al-Khadrā. 2001.

Khālid bin Hāmid al-Hāzimī. 2000. Ushūl at-Tarbiyyah al-Islāmiyyah. Madinah: Dār alĀlam al-Kutub.

Labudasari, Erna, and Eliya Rochmah. 2019. "Pengaruh Gerakan Literasi Sekolah Terhadap Karakter Mandiri Siswa Di SDN Kanggraksan Cirebon." Premiere Educandum : Jurnal Pendidikan Dasar Dan Pembelajaran 9(1):57. doi: 10.25273/pe.v9i1.4254.

Lizawati, Lizawati, and Indriyana Uli. 2018. "Implementasi Nilai Pendidikan Karakter Dalam Sastra Lisan Di IKIP PGRI Pontianak." Premiere Educandum: Jurnal Pendidikan Dasar Dan Pembelajaran 8(2):140. doi: 10.25273/pe.v8i2.2911.

Mansor, Rosnidar, Tanjung Malim, Suppiah Nichiappan, and Tanjung Malim. 2019. "The Implementation of Role of Kuttab Al-Fatih ( KAF ) Philosophy in Islamic Character Education Introduction The Subsequent Cultural Differences in Educational Philosophy Used between Western and Eastern Nations . The Rationalism Has given Secularism in K." 13(2).

Muhammad Musa as-Syarif. 2001. Al-Athifah al-Imaniyyah wa Ahammiyatuha fi al-A'mal al-Islamiyyah. Saudi: Dar al-Andalus al-Khadra. 2001.

Nafi, Dedik Muksinun, and Wasito. 2019. "Intregasi Model Pembelajaran Pesantren Di Sekolah Formal: Studi Kasus Di SMP Islam As-Syafiah Mojosari Kec. Loceret Nganjuk Dedik Muksinun Nafi, 1 Wasito 2 1." Intelektual Jurnal Pendidikan Dan Studi Keislaman 9(April):79-90.

Nasir, Muhammad. 2020. "Curriculum Characteristics of Madrasah Aliyah in East Kalimantan." Dinamika Ilmu 20(1):95-105. doi: 10.21093/di.v20i1.2215.

Nugroho, Puspo. 2017. "Internalisasi Nilai-Nilai Karakter Dan Kepribadian Mahasiswa Pendidikan Agama Islam Melalui Pendekatan Humanis-Religius." Edukasia : Jurnal Penelitian Pendidikan Islam 12(2):355. doi: 10.21043/edukasia.v12i2.2491.

Nurdin, Indra Fajar. 2015. "Perbandingan Konsep Adab Menurut Ibn Hajar Al-'Asqalany Dengan Konsep Pendidikan Karakter Di Indonesia." Jurnal Pendidikan Islam 4(1):159. doi: 10.14421/jpi.2015.41.159-187.

Ramdan, Ahmad Yasar, and Puji Yanti Fauziah. 2019. "Peran Orang Tua Dan Guru Dalam Mengembangkan Nilai-Nilai Karakter Anak Usia Sekolah Dasar." Premiere Educandum: Jurnal Pendidikan Dasar Dan Pembelajaran 9(2):100. doi: 10.25273/pe.v9i2.4501.

Rasikh, Ar. 2018. “PEMBELAJARAN KITAB KUNING PADA PONDOK PESANTREN KHUSUS 
AL-HALIMY DESA SESELA KABUPATEN LOMBOK BARAT Pendahuluan Pondok Pesantren Adalah Salah Satu Lembaga Yang Menyelenggarakan Pendidikan Baik Formal Maupun Non Formal , Yang Memiliki Peran Strategis Dalam." Jurnal Penelitian Keislaman 14(1):71-84.

Rodiah, Zulkarnain, and Qolbi Khoiri. 2018. "Implementasi Metode Sorogan Dalam Pembelajaran Kitab Kuning Di Pondok Pesantren Al-Munawwaroh Kab. Kepahiang Provinsi Bengkulu." Jurnal Literasiologi 1(1):37-58.

Rusmin B., Muhammad. 2017. "Konsep Dan Tujuan Pendidikan Islam." Inspiratif Pendidikan 6(1):72. doi: 10.24252/ip.v6i1.4390.

Rustan, Edhy, Nurul Hanifah, and Bulu' Kanro. 2018. "De-Radicalization in the Implementation of Islamic Education Curriculum in SMA Masamba South Sulawesi." Dinamika Ilmu 18(2):271-83. doi: 10.21093/di.v18i2.1338.

S. A. P., Rangga Sa'adillah. 2015. "Pendidikan Karakter Menurut Kh. Wahid Hasyim.” Jurnal Pendidikan Agama Islam (Journal of Islamic Education Studies) 3(2):276. doi: 10.15642/pai.2015.3.2.276-303.

Sajadi, Dahrun. 2019. "Pendidikan Karakter Dalam Perspektif Islam.” Tahdzib Al-Akhlaq: Jurnal Pendidikan Islam 2(2):16-34. doi: 10.34005/tahdzib.v2i2.510.

Sa'īd Ismāil Alī. 2000. Al-Quran al-Karim Ru'yatan Tarbawiyyatan. Cairo: Dar al-Fikri alArabi.

Sa'îd Ismāil Alī. 2002. As-Sunnah An-Nabawiyyah Ru'yatan Tarbawiyyatan. Cairo: Dar alFikri al-Arabi.

Supa'at, Supa'at. 1970. “Model Kebijakan Pendidikan Karakter Di Madrasah.” Jurnal Pendidikan Islam 3(1):203. doi: 10.14421/jpi.2014.31.203-225.

Tolib, Abdul. 2015. "Pendidikan Di Pondok Pesantren Modern.” Risalah 1(1):60-66.

Ulya, Inayatul. 2017. "Internalisasi Karakter Sensitif Gender Dalam Kurikulum Pendidikan.” Edukasia Islamika 2(1):107. doi: 10.28918/jei.v2i1.1664.

Wihyanti, Retno. 2018. "DALAM KEDIVERSITASAN ETNIS DI SEKOLAH A . Pendahuluan Kehidupan. Selain Indonesia Memiliki Keragaman Dalam Aspek 15 , 50 Persen . Suku-Suku Indonesia Lainnya Memiliki Proporsi." Jurnal Penelitian Pendidikan Islam 13(1):79-104.

Wulandari, Anis, Jawa Tengah, Zakiyuddin Baidhawy, and Jawa Tengah. n.d. "Implementasi Sistemik Pendidikan Karakter Di Lembaga Pendidikan Islam A . Pendahuluan Lembaga Pendidikan Islam Merupakan Wadah Yang Sangat Strategis Untuk Proses Yang Berkesinambungan Dalam Pendidikan Dan Pembudayaan Sikap Positif Sebagai Upaya Mewujudkan." 14(2):463-82.

Zulfa, Umi. 2018. "Model of Islamic Religion Education 435 Based on Islam Nusantara on College Umi Zulfa Imstitut Agama Islam Ghazali ( IAIG ) Cilacap Introduction . Indonesia Care about Religious Issues and Religious Education Citizens, Even Religious Education Becomes Th.” 12(51). 